\title{
CASE REPORT OF LANGERHANS CELL HISTIOCYTOSIS
}

D. V. Umesh Reddy ${ }^{1}$, G. Somaiah², K. Ravikanth ${ }^{3}$, R. Navneeth Reddy ${ }^{4}$ M. Gowthami ${ }^{5}$

\section{HOW TO CITE THIS ARTICLE:}

D. V. Umesh Reddy, G. Somaiah, K. Ravikanth, R. Navneeth Reddy, M. Gowthami. "Case Report of Langerhans Cell Histiocytosis". Journal of Evolution of Medical and Dental Sciences 2014; Vol. 3, Issue 38, August 25;

Page: 9764-9767, DOI: 10.14260/jemds/2014/3263

ABSTRACT: Langerhans cell histiocytosis (LCH) is a rare proliferative disorder in which pathological Langerhans cells (LCs) accumulate in a variety of organs. This report describes a boy with Langerhans' cell histiocytosis who presented with primarily soft tissue swellings, without pain. A high index of suspicion is required to reach to a diagnosis of langerhans cell histiocytosis to prevent delay in proper management of this disease.

KEYWORDS: Langerhans cell, bierbeck granules, osteolytic lesions.

INTRODUCTION: The childhood histiocytoses, although individually rare, varies widely in its clinical expression. These disorders are grouped together because they have in common a prominent proliferation or accumulation of cells of the monocyte-macrophage system of bone marrow origin. [1] A systematic classification of the childhood histiocytoses is based on histopathologic findings. The name Langerhans cell histiocytosis (LCH) has been applied to the class I histiocytoses.

The normal Langerhans cell is an antigen-presenting cell of the skin. The hallmark of LCH in all forms is the presence of a clonal proliferation of cells of the monocyte lineage containing the characteristic electron microscopic findings of a Langerhans cell. This is the Birbeck granule, a tennis racket-shaped bilamellar granule that, when seen in the cytoplasm of lesional cells in LCH, is diagnostic of the disease. [1]

CASE REPORT: A 4 year old male child presented to our pediatric outpatient department of mamata medical college with the chief complaint of multiple swellings over the forehead for the last one year. The child was apparently normal one year back when his parents noticed multiple small swellings which were gradually progressing in size. The child is a product of non-consanguineous marriage, full term, normal vaginal delivery and has a younger sister who is doing well.

On examination there were three swellings over the forehead, which were subcutaneous, nontender margins ill-defined and with underlying bony defects in center of the swellings. Bilateral exophthalmos was present There was no organomegaly, generalized lymphadenopathy, skin manifestations or ear discharge.

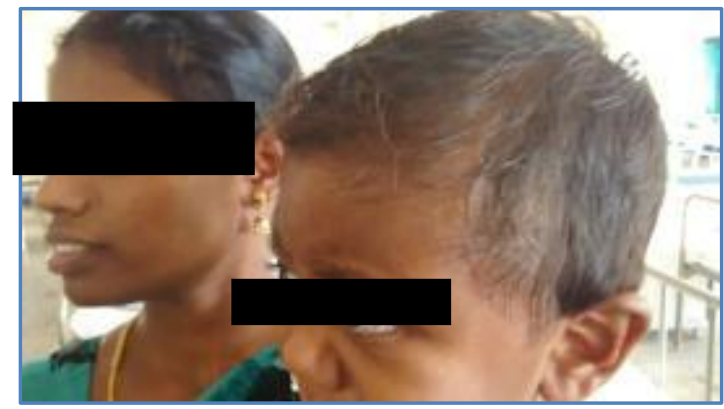

Fig. 1: Mild bilateral exopthalmous present

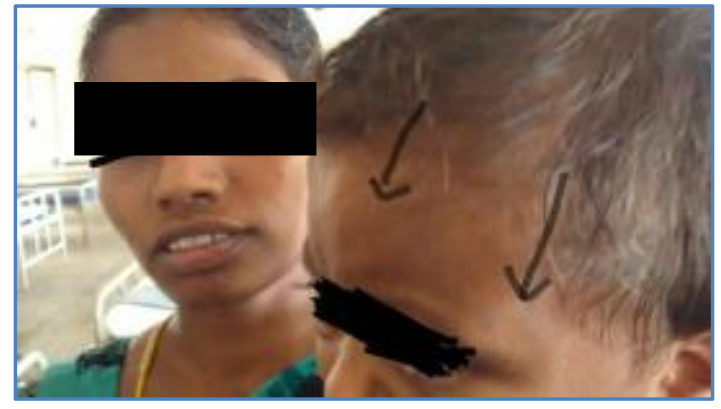

Fig. 2: Swellings in the Fore head region (black arrows) 


\section{CASE REPORT}

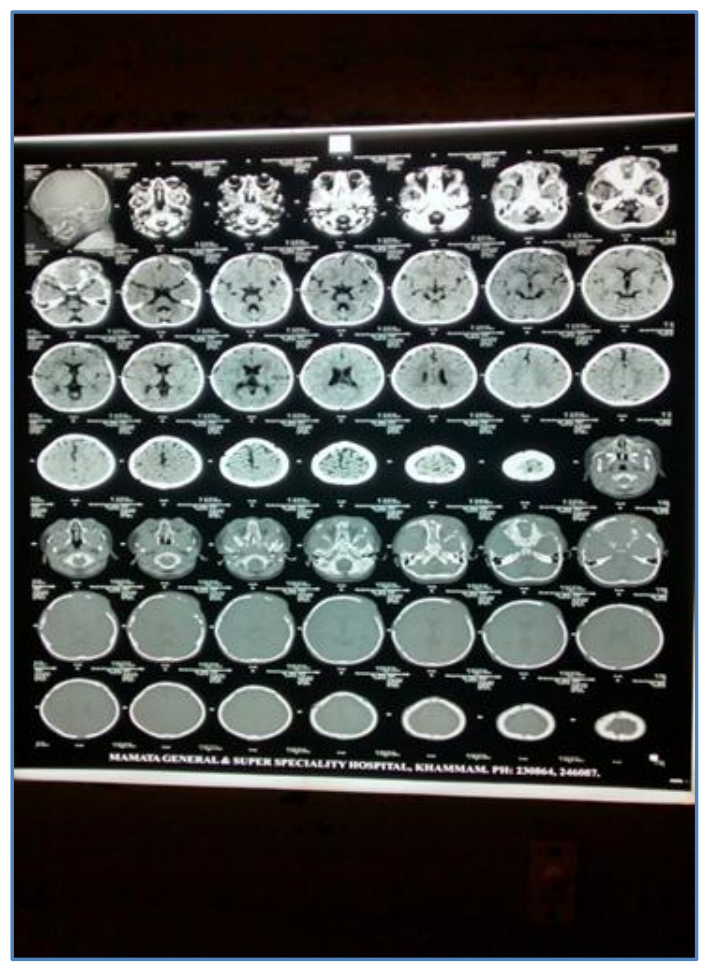

Fig. 3: CT scan showing multiple osteolytic lesions of the skull bones

Fig. 4: Skiagram of the skull showing multiple osteolytic lesions in the skull bones (blue arrows). X-rays of pelvis, spine and femur were taken which were normal.

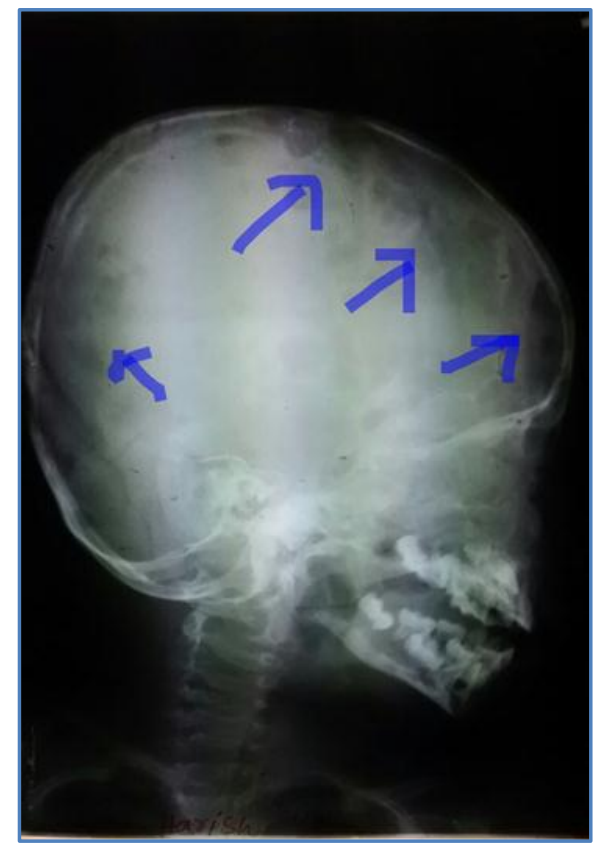

Fig. 4 
Other investigations revealed $\mathrm{Hb} 10.2 \mathrm{gm} / \mathrm{dl}$, ESR 25mm, normal differential leucocyte counts, triglyceride levels, serum osmolality and liver function tests.

Histologic examination of a punch biopsy obtained from the lesion revealed diffuse replacement of the superficial dermis by enlarged mononuclear cells admixed with numerous eosinophils. These mononuclear cells had abundant eosinophilic cytoplasm and reniform nuclei. The epidermis was focally ulcerated adjacent to areas in which there was epidermotropism of the mononuclear cells (Fig. 4). Tumoral cells demonstrated strong positivity with S100 and CD1a immunohistochemical stains.

Fig. 5: Marked decoration of Langerhans cells with CD1a.

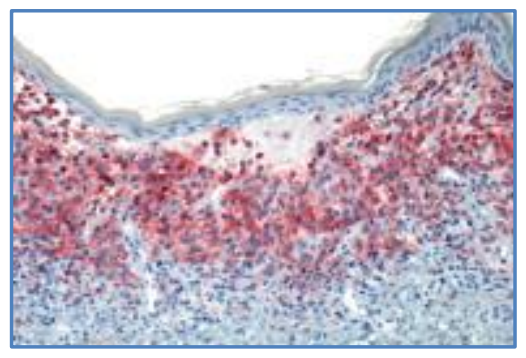

\section{Fig. 5}

DISCUSSION: This initial classification system included: Langerhans histiocytosis (Class I), nonLangerhans cell histiocytosis (Class II), and malignant histiocytosis (Class III).[2] As more information has become available, a revised classification schema was proposed and includes: dendritic cell disorders, macrophage-related disorders, and lastly, malignant histiocytic disorders. ${ }^{[3]}$

LCH has an extremely variable presentation. The incidence of LCH ranges from 0.5 to 5.4 cases per million persons per year, depending upon the age of the population investigated.[4- 6]

Although no clear etiology has been identified, the general consensus is that patients with LCH have a dysregulated immune response with failed transition from "innate" to "adaptive" immunity. ${ }^{[7,8]}$ The skeleton is involved in $80 \%$ of patients and may be the only affected site. Bone lesions may be single or multiple and are seen most commonly in the skull.

They may be asymptomatic or associated with pain and local swelling. Exophthalmos, when present, often is bilateral and is caused by retro-orbital accumulation of granulomatous tissue. The clinical course of single-system disease (usually bone, lymph node, or skin) generally is benign, with a high chance of spontaneous remission.

Several large retrospective studies consisting of neonates and children under the age of 4 have shown that 51 percept to 71 percent of children with LCH present with multi organ disease. $[4,7,9,1011]$ our index case presented only with isolated skull bones involvement and the prognosis depends chiefly upon the involvement of multiple organ systems, organ dysfunction and the patient's response to chemotherapy during the initial 6 weeks of treatment.

\section{REFERENCES:}

1. Ladisch S. Histiocytosis Syndromes in Childhood, Chapter 501, Nelson Textbook of Pediatrics, 18 e.

2. Chu T, D'Angio GJ, Favara B, Ladisch S, Nesbit M, Pritchard J. Histiocytosis Syndromes in Children. Writing Group of the Histiocyte Society. Lancet 1987; 2 (8549): 41-42. 
3. Favara BE, Feller AC, Pauli M, Jaffe ES, Weiss LM, Arico M et al. Contemporary Classification of Histiocytic Disorders. The WHO Committee on Histiocytic/Reticulum Cell Proliferations. Reclassification Working Group of the Histiocytic Society. Med Pediatr Oncol 1997; 29 (3): 157-166.

4. Alston RD, Tatevossian RG, McNally RJ, Kelsey A, Birch JM, Eden TO. Incidence and survival of childhood Langerhans cell histiocytosis in Northwest England from 1954 to 1998. Pediatr Blood Cancer 200748 (5): 555-560.

5. The French Langerhans' Cell Study Group. A multicenter retrospective survey of Langerhans' cell histiocytosis: 348 cases observed between 1983 and 1993. Arch Dis Child 1996; 75 (1): 17 24

6. Schmitz L, Favara BE. Nosology and pathology of Langerhans cell histiocytosis. Hematol Clin North Am 1998; 12 (2): 222-246.

7. Bhatia S, Nesbit ME Jr, Egeler RM, Buckley JD, Mertens A, Robison LL. Epidemiologic study of Langerhans cell histiocytosis in children. J Pediatr 1997; 130 (5): 774-784.

8. Savasan, S. An enigmatic disease: childhood Langerhans cell histiocytosis in 2005. Int J Dermatol 2006; 45 (3): 182-188.

9. Isaacs H Jr. Fetal and neonatal histiocytoses. Pediatr Blood \& Cancer 2006; 47 (2): 123-129.

10. Longaker, MA, Frieden IJ, LeBoit PE, Sherertz EF. Congenital "self-healing" Langerhans cell histiocytosis: The need for long-term follow-up. J Am Acad Dermatol 1994; 31 (5 Pt 2): 910916.

11. Stein SL, Paller AS, Haut PR, Mancini AJ. Langerhans cell histiocytosis presenting in the neonatal period: a retrospective case series. Arch Pediatr Adolesc Med 2001; 155 (7): 778-83.

\section{AUTHORS:}

1. D. V. Umesh Reddy

2. G. Somaiah

3. K. Ravikanth

4. R. Navneeth Reddy

5. M. Gowthami

\section{PARTICULARS OF CONTRIBUTORS:}

1. Post Graduate Student, Department of Paediatrics, Mamata Medical College \& Mamata General Hospital.

2. Professor and Guide, Department of Paediatrics, Mamata Medical College \& Mamata General Hospital.

3. Post Graduate Student, Department of Paediatrics, Mamata Medical College \& Mamata General Hospital.

4. Post Graduate Student, Department of Paediatrics, Mamata Medical College \& Mamata General Hospital.
5. Post Graduate Student, Department of Paediatrics, Mamata Medical College \& Mamata General Hospital.

\section{NAME ADDRESS EMAIL ID OF THE CORRESPONDING AUTHOR:}

Umesh Reddy,

Department of Paediatrics,

Mamata Medical College \&

General Hospital,

Khammam, Telangana,

Email: umeshreddyd@gmail.com

Date of Submission: 30/07/2014.

Date of Peer Review: 31/07/2014.

Date of Acceptance: 20/08/2014.

Date of Publishing: 23/08/2014. 